\title{
Experimental Investigation of Adding Albocarbon on Otto Engine Efficiency
}

\author{
Munther Abdullah Mussa
}

\begin{abstract}
Albocarbon is an aromatic hydrocarbon solid compound. It has distinguishing odor with white crystalline structure. Most of Albocarbon today is produced from coal tar and used in paints, explosives, solvent and the most popular use as expeller of moths. In this research, Albocarbon had been examined to be as Fuel Enhancer for Otto engines. Four samples of the mixture of gasoline with Albocarbon as additive have been prepared, first is the control which was pure gasoline and the three others were different percentage of Albocarbon to the total mixture. In terms of chemical interaction, two methods have been used for identification of chemical compounds. Fourier transform infrared spectroscopy (FTIR) which is identified the functional group in the samples and the second is gas chromatography with mass spectrometry (GC-Mass) to measure the total ions in the samples. The effects of the addition on the mechanical characteristics have been tested using single cylinder four-stroke gasoline engine with hydraulic dynamometer. It has been proved that the adding of Albocarbon increases the Octane number and increases the total energy obtained from the fuel. However, these increments have a limit in their values and excess added may leads to fixed enchantment with more harmful precipitations.
\end{abstract}

Keywords-Albocarbon, Octane number, addtives, gasoline, Naphthalene

\section{Introduction}

Increasing fuel Octane number for Otto engines actually accomplishes two goals. It prevents the engine parts from damage or failure due to high pressure of knocking or advance ignition. When the ignition occurs at the precise time for high Octane number fuel, the total released heat from the explosion can be converted to pressure and consequently torque. This increases the thermal efficiency of the engine, which may be consider the second achievement of increasing fuel Octane number.

Many attempts to boost the Octane Number using additives have been done by previous researchers [1][2][3]. Most of them focus on use different chemical liquids compound of high Octane number as additive by mixing them at different ratios with gasoline to rise its Octane number. However, even they succeed to increase the Octane number, they face several problems, not the least, reduced the energy obtained from the amended fuel [4][5][6] and non-predicted effects of new chemicals in the various engine components such as metal parts and rubber [7][8]. Actually, these two adverse effects cancel the two achievements of increasing fuel Octane number, which had mentioned above.

The complex mixture of gasoline consist of hundreds of volatile and combustible compounds derived from crude oil

Munther Abdullah Mussa

College of Engineering / University of Baghdad Iraq with 4-12 carbon atoms at $84-87 \%$ ratio of total chemical elements and their boiling points in the range of $30-220^{\circ} \mathrm{C}$. Whereas hydrogen percentage is $11-14$ percent by weight [9].

The hydrocarbons present in gasoline are classified into four general types: paraffins, isoparaffins, naphthenes and aromatics. These compounds show effects on octane number. Actually the presence of aromatic hydrocarbons, isoparaffins and Olefin derivatives such as ethanol and esters could be increase the octane number of gasoline [10]. The increment accurse in processes such as reforming, isomerization, cracking and alkylation [10]. The long-chain alkanes in gasoline fraction have to be converted into shorter chain and isoalkanes, which is more active in petrol, more than other types of hydrocarbons like cycloalkanes that is also present in gasoline. Therefore, there are great influence of chemical structure on detonation. Olefins with less than four carbon atoms and aromatics has strong resistant to self detonation, inversely, the long chains paraffins and olefins, with more than four carbon atoms, are more susceptible to self-detonation [9].

Albocarbon or Naphthalene is an aromatic organic hydrocarbon its molecular formula is $\mathrm{C} 10 \mathrm{H} 8$, which represent two fused of benzene rings. It can be produced from either crude oil or coal tar thus it's inexpensive and can be supplied abundant quantities. That being aromatic and low-cost, makes it a promising additive to boost gasoline Octane number without fear of its effects on the thermal efficiency or engines parts like the others chemical additives.

Several of internet websites talk about using Albocarbon in the form of mothball as Octane booster for long time ago; even some of them return that to World War 1 [11]. However, there is no any scientific research paper or Journal article discuss it to know the advances and dis-advances of this method in scientific approach. In this study, an attempt to join this gap will do by find the effects of adding several ratios of Albocarbon to gasoline on the thermal performance and emissions of Otto engine.

\section{Experimental work}

Four gasoline-Albocarbon mixtures have been settled. These blends prepared by mix a certain portions of Albocarbon with fixed amount of gasoline. Sample A is a pure gasoline; B, C and D are 0.001, 0.004 and 0.008 of Albocarbon respectively. Table I shows the properties of gasoline [12], Albocarbon [13]. The total experimental works can be divided into four parts as follow.

\section{A. Octane Number Analysis}

To inspect the Octane number of the prepared blends, SHATOX SX-100M ${ }^{\mathrm{TM}}$ portable octane analyzer was used. It measure the dielectric properties of the samples and 
compare the results for the standard factors of typical compounds of fuel, which are stored in its internal memory. According to the high sensitivity of the device to dielectric characteristics, it is a very efficient tool to measure the Octane number and many of other chemical properties of the fuel. The device have been previously calibrated using the Cooperative Fuel Research (CFR) engine and all its results are highly trusted.

TABL I FUEL PROPERTIES

\begin{tabular}{|c|c|c|}
\hline & Albocarbon & Gasoline \\
\hline Molecular formula & $\mathrm{C}_{10} \mathrm{H}_{8}$ & $\mathrm{C}_{4}$ to $\mathrm{C}_{12}$ \\
\hline Molecular weight & 128.18 & $95-120$ \\
\hline Density $\left(\mathbf{k g} / \mathbf{m}^{\mathbf{3}}\right)$ & 1162 & 740 \\
\hline LHV $(\mathbf{M J} / \mathbf{k g})$ & 40.24 & 44.3 \\
\hline Auto-ignition temperature $\left({ }^{\circ} \mathbf{C}\right)$ & 540 & $228-470$ \\
\hline Latent heat $(\mathbf{k J} / \mathbf{k g})$ & 338 & 305 \\
\hline Boiling point $\left({ }^{\mathbf{0}} \mathbf{C}\right)$ & 218 & $38-204$ \\
\hline
\end{tabular}

\section{B. Fourier Transform Infrared spectroscopy (FT-IR) Analysis}

Liquid membrane method involves dripping several drops of the sample onto a $\mathrm{KBr}$ aperture plate and sandwiching it under another aperture plate, such that no gas babbles are trapped. The thickness is adjusted according to the sample absorbency. Place the plates into the sample holder and run a spectrum. The $\mathrm{KBr}$ plates must be thoroughly cleaned after the procedure to prevent contamination of future samples.

\section{Gas Chromatography-Mass Spectrometry (GC-MS)Analysis}

The chemical composition of the gasoline blends was obtained using Electron-Ionization Mass Spectrometry (EIMS). The analyses were performed in a GC-MS SHIMADZUTM, using a fused capillary column (50 m x 0.2 $\mathrm{mm} \times 0.5 \mu \mathrm{m}, \mathrm{PONA} 50, \mathrm{HP})$, through poly(methylsiloxane) as the stationary phase and helium as the career gas with a constant flow rate of $0.1 \mathrm{~mL}$ min-1. Blends gasoline of 1.0 $\mu \mathrm{L}$ were injected in split mode $(1: 16)$ without solvent delay. The analyses were achieved in the mentioned conditions: Injector temperatures was $230^{\circ} \mathrm{C}$, detector temperature was $250^{\circ} \mathrm{C}$. The presence of different types of compounds in the samples was conformed using total ion chromatogram (TIC) together with library information. Hydrocarbons with less than $90 \%$ similarity of mass spectra were exclude.

\section{Performance and Emissions Measurements}

The test unit consists of the engine, the control board and the auxiliary unit, which is composed of the fuel system, air intake system and the complementary parts of the engine cooling system. (Fig. 1)

The main device in the unit is the engine, which is a fourstroke single cylinder Otto engine manufactured by PRODIT $^{\mathrm{TM}}$. The bore diameter is $90 \mathrm{~mm}$ with $85 \mathrm{~mm}$ stroke and the compression ratio is 6.5. The engine is water cooled with plate-type heat exchanger. The engine torque is measured by hydraulic dynamometer designed in such a way that high torque and high response speed can be reached while the water from the dynamometer is conveyed to the discharge.

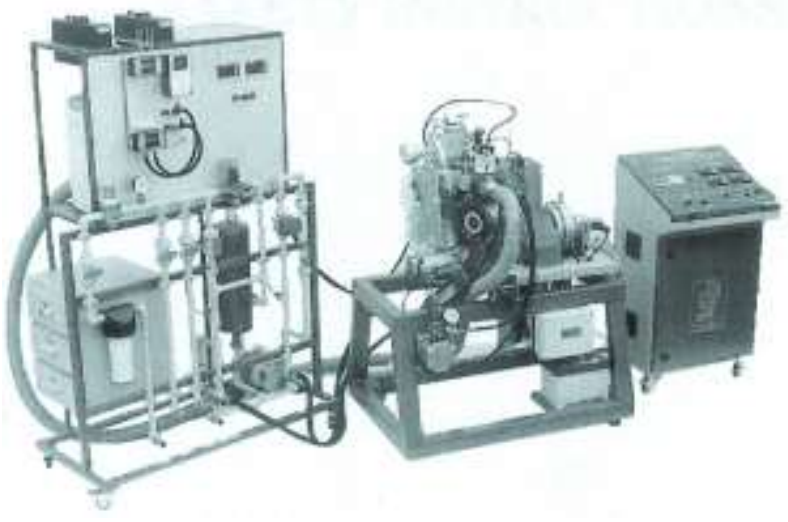

Figure 1. The Test Bench Unit

The dynamometer is supplied with a load cell with strain gauges. The load cell signal turns out to be directly proportional to the engine torque. The output signal from the transducer is transmitted through electric cables to the torque display screen placed on the control board. The fuel discharge can be measured by a fuel flow meter, which is composed of known size burette, chronometer with digital display, and two ways valve. When the valve settled on the measurement position, the engine draws the fuel from the adjusted burette and the chronometer start. It stop when the fuel reaches the lower sign and the result showed on the LCD. The air consumption by the engine circulates inside air suction pipe and produce a pressure drop proportional to air speed. The differential pressure transducer transfer a signal according to this pressure drop. This signal sent to the digital display on the control board to show the air intake by the engine. The engine starting, gasoline throttle control and brake control valve can be controlled on the control board, which also contain speed display in addition to torque display and airflow display as mentioned previously. The experiments had been done using the engine on three speed values of $1200,1500,1800$ r.p.m with load range 10-14 kN.m. All the tests have been done under same environmental condition such as temperature and relative humidity to avoid the effects of different weather conditions on the intake air or other factors. The data collections have been done after the engine warming up to reaches its steady state temperature to evade the different conditions of engine thermal properties during heating up period. The air intake throttle valve had been settled on fully open condition.

To measure the exhaust gas emissions, the Flux 2000-4 gas-analyzer had been used. It is an infra-red microprocessor based photometer designed to measure the proportion of $\mathrm{CO}, \mathrm{CO} 2$, RHC (Residual Hydrocarbons) and excess oxygen in the exhaust gas of internal combustion engines. It is measures $\mathrm{CO}, \mathrm{CO} 2$, RHC concentrations using NonDispersive Infra-Red (NDIR) technique and it uses an electrochemical transducer to find Oxygen ratio. Table II shows the measurements ranges and technical properties of the device.

To keep the accuracy of the measurement the device makes auto-zeroing at the start of every gas intake and it provided with drainage system to automatic condensate any water residual in the device and drain it out. 
Proc. of the Fourth Intl. Conf. Advances in Civil, Structural and Mechanical Engineering- CSM 2016 Copyright (C) Institute of Research Engineers and Doctors, USA .All rights reserved.

ISBN: 978-1-63248-093-4 doi: 10.15224/ 978-1-63248-093-4-49

TABL II GAS ANALAZER TECHNICAL PROPERTIES

\begin{tabular}{|c|c|}
\hline $\mathbf{C O}$ & $0-9.99 \%$ vol \\
\hline $\mathbf{C O}_{2}$ & $0-19.9 \%$ vol \\
\hline RHC & $0-19990 \mathrm{ppm}$ \\
\hline $\mathbf{O}_{2}$ & $0-25 \%$ vol \\
\hline Warm-up time & $30 \mathrm{~min}$ \\
\hline Response time & Approx. $15 \mathrm{sec}$ \\
\hline Operating temperature & $5-40^{\circ} \mathrm{C}$ \\
\hline
\end{tabular}

The device is computes Lambda $(\lambda)$, which is the fraction of actual air to fuel ratio (AFR) to stoichiometric ratio. It is using Brettschneider equation [14], which is a complicated formula, using $\mathrm{CO}, \mathrm{CO}_{2}, \mathrm{RHC}$ and $\mathrm{O}_{2}$ values in the exhaust gas to find Lambda. For gasoline fuel, the device directly displays AFR depending on $\lambda$ and gasoline corrected stoichiometric ratio (14.7) [15]. The built-in impact printer can print all the data measured and calculated by the device in a report.

\section{Results and discussions}

At the preparing stage of the blends, it can be noticed that when increasing the concentration of the added Albocarbon more than $0.001 \%$ there will be an insoluble part deposit down the beaker. This indicate that Albocarbon has low solubility in gasoline and increasing the concentration is not a good idea because any rate above the edge concentration will be forceless. The results obtained from Octane meter analyzer confirmed this notion. Table III shows the test results of Octane number. It can be seen that the change in Octane number values is limited to blend $\mathrm{B}$ and not too much increment and above that concentration, there is no any real change in the Octane rates even when increase Albocarbon rate.

TABL III OCTANE NUMBER TESTS RESULTS

\begin{tabular}{|c|c|c|c|}
\hline & RON & MON & AKI \\
\hline A & 92.6 & 83 & 88 \\
\hline B & 93.2 & 83.9 & 88.5 \\
\hline C & 93.2 & 83.8 & 88.5 \\
\hline D & 92.6 & 83.5 & 88.1 \\
\hline
\end{tabular}

The results obtained by GC/MS show that blend B becomes more concentrated in aromatics compounds (as toluene) compared to control blends (blend A). Cyclic Paraffins (as cyclopentane) and olefins (as 2-pentene 2,4,4,trimethylene) also showed increment in their percent when compared to the control. In contrast, paraffins appeared lower concentration compared to blends $\mathrm{A}$. When used more Albocarbon concentration in blends $\mathrm{C}$ and $\mathrm{D}$, decrement in aromatic and olefins compounds have been represented in Fig 2. In contrast there are increasing in isoparaffins content, whereas paraffines still show mild decrement in their concentrations compared to blends A. Aromatic, cyclic paraffins and olefins compounds have been approved that in sample B their ratio is around $85.23 \%$. Mendes et al. [9] has confirmed these compounds as a high MON values compounds. Samples C and D show lower content of aromatic, cyclic paraffins and olefins $(63.3 \%$ and $54.54 \%$ respectively). The result agree with the data gained from the Octane number IRdevice. The low solubility of naphthalin could be comes behind the moderate difference in Octane number. Fig. 2 showed the increment in naphthaline concentration with increasing it is concentration in the blends. As well as the effect of naphthalin solubility, the gradual raise of isoparaffins content from blend A to D may plays a role. This role is not effective when there is a balance between the compounds. FTIR results support the presence of the five main compounds in the four blends. It diagnosed the active groups (like $\mathrm{C}=\mathrm{C}$ aromatic, $\mathrm{C}-\mathrm{C}, \mathrm{C}-\mathrm{H}$ aliphatic and $\mathrm{C}-\mathrm{H}$ aromatic)

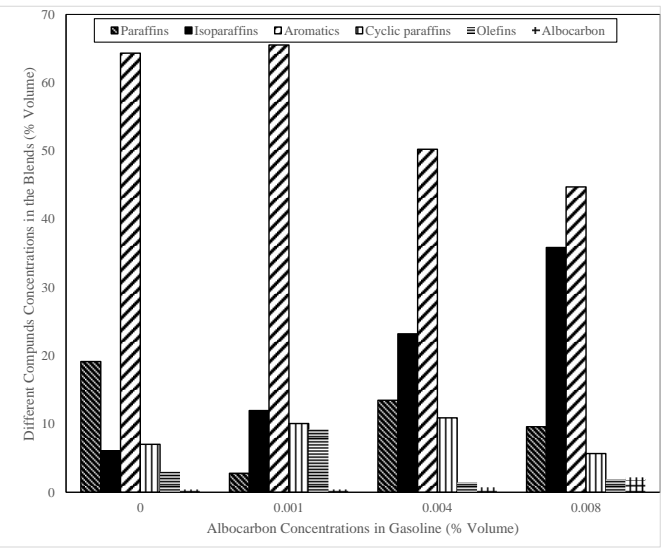

Figure 2. Gasoline Different Compounds Concentrations in the Blends

It can be seen from Fig. 3. The effect of adding Albocarbon to the gasoline in the fuel consumption. It has been approved that adding Albocarbon is enhance the specific fuel consumption slightly and it clear also that the decrement in the fuel consumption is higher in the low and high engine speeds than in moderate speed. No much difference had been noticed between blend $\mathrm{C} \& \mathrm{D}$, which agree with the Octane meter analyzer results.

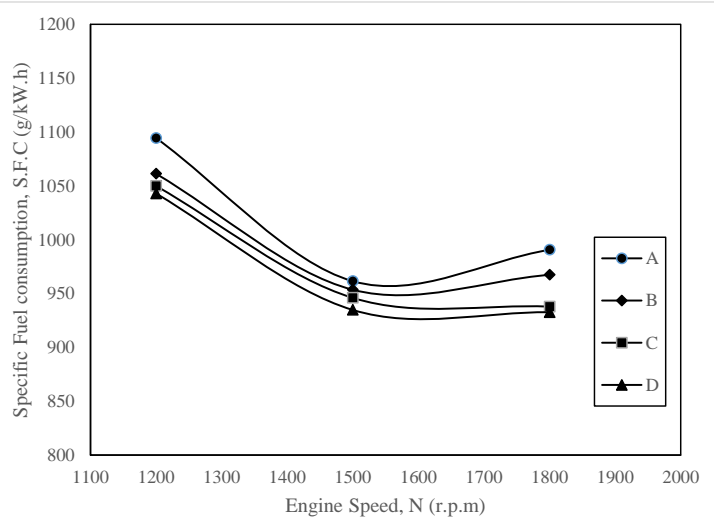

Figure 3. Albocarbon blends effects on the specific fuel consumption for different engine speed

Fig. 4 represents the brake power against engine speed. This graph shows that adding Albocarbon leads to increasing in the delivered power for the same engine speed. It also demonstrates that the difference between the Albocarbon blends C \& D is not too effective. This is congruent to Fig 3 and Octane tests results.

Fig. 5 also agrees with the above facts. It shows the effects of Albocarbon concentrations on the brake thermal efficiency. It can be seen the increment of the brake thermal efficiency due to Albocarbon additions and at the same time there is no big difference between the blends effects on the efficiency effects. 
Proc. of the Fourth Intl. Conf. Advances in Civil, Structural and Mechanical Engineering- CSM 2016

Copyright (C) Institute of Research Engineers and Doctors, USA .All rights reserved.

ISBN: 978-1-63248-093-4 doi: 10.15224/ 978-1-63248-093-4-49

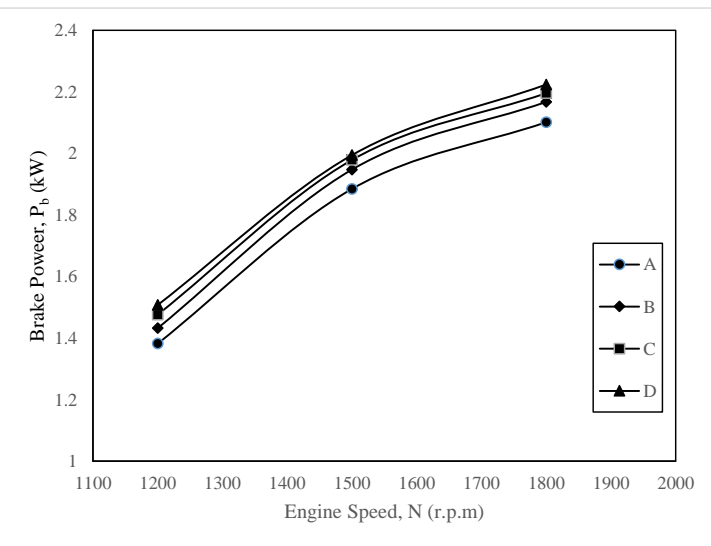

Figure 4. Albocarbon blends effects on the brake power for different engine speed

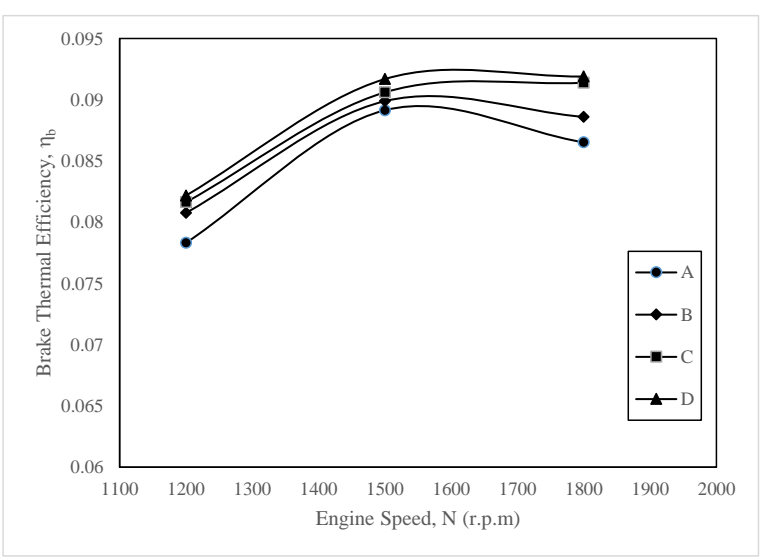

Figure 5. Albocarbon blends effects on the brake thermal efficiency for different engine speed

Fig. 6, $7 \& 8$ shows the effects of adding Albocarbon on the concentrations of $\mathrm{CO}, \mathrm{CO} 2$ and $\mathrm{RHC}$ respectively.

Fig. 6 reveals that increasing Albocarbon leads to significantly increasing in the $\mathrm{CO}$ rates. It obviously clear that even the high rate blend $\mathrm{D}$ have no effect on the Octane number or small effect on the performance as previously cleared, but it still increasing the bad concentrations of $\mathrm{CO}$ gas. While Fig. 7 shows opposite effects where increasing Albocarbon rates leads to decreasing in the concentrations of $\mathrm{CO} 2$. For high engine speeds, the difference between the blends become small where all of them have small rates of $\mathrm{CO} 2$ gas. This trend is similar in some way to Fig. 8 tendency, where the rates of unburned hydrocarbons decreased according to increasing in Albocarbon concentrations but with big difference between the blends for high engine speeds.

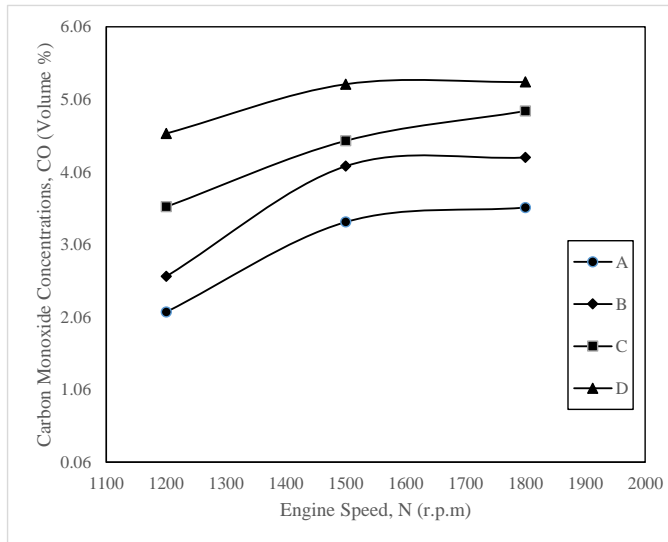

Figure 6. Albocarbon blends effects on the Carbon Monoxide concentrations in exhaust gas

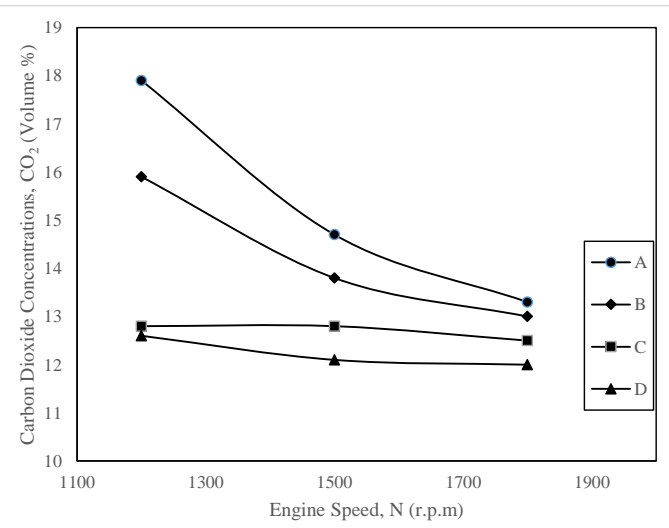

Figure 7. Albocarbon blends effects on the Carbon Dioxide concentrations in exhaust gas

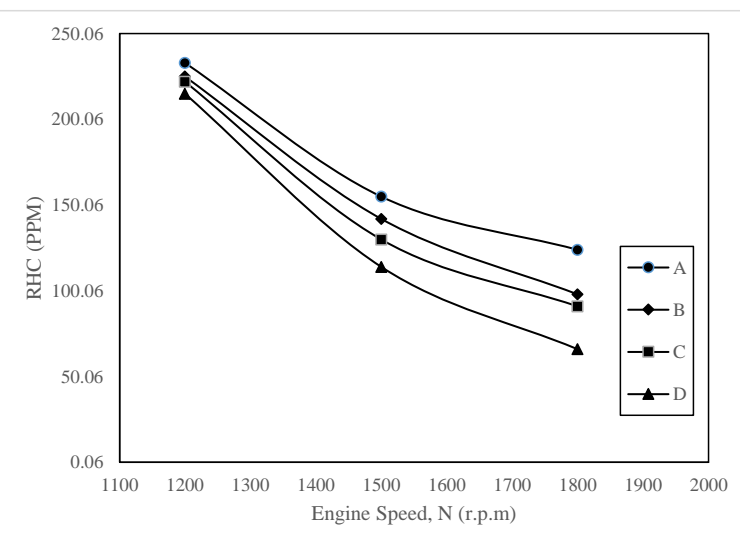

Figure 8. Albocarbon blends effects on the Residual Hydrocarbon concentrations in exhaust gas

\section{Conclusions}

The effects of using Albocarbon as fuel additive had been investigated. Four blends of gasoline and different concentration of Albocarbon have been examined. Four main tests have been achieved for the four blends, Octane number examination, (FT-IR) analysis, (GC-MS) analysis and performance with exhaust gas investigations. The results obtained from all of these experiments consensus on some of major conclusions. The first illation is the adding small quantity of Albocarbon leads to small increment in the Octane number as well as small increment in the specific 
fuel consumptions thus the total effects will be significant increasing in the total brake power and the thermal efficiency. The second conclusion is if adding Albocarbon to gasoline in high concentration there will be some rate of low solubility of naphthalin, which will give inverse effects of the dissolved naphthalin. In this case also there will be an amount of down deposited naphthalin, which may block the fuel filters or small diameter pipes if it used directly in the storage tank of the car. Another obtained inference, which can be observed from gas analyzer results is increasing Albocarbon rates leads to decreasing in the pollution come from $\mathrm{RHC}$ and $\mathrm{CO} 2$ but it increases $\mathrm{CO}$ concentration so due to combustion curve if can increase the inlet air, the bad effects of increasing $\mathrm{CO}$ rates can be eliminated. In total, Adding Albocarbon is a good choice to enhance the performance of the engine but with two conditions; first is use small rates and the second is dissolved it in a separate fuel bottle before add it to the fuel tank.

\section{References}

[1] X. Wang, Z. Chen, J. Ni, S. Liu, and H. Zhou, "The effects of hydrous ethanol gasoline on combustion and emission characteristics of a port injection gasoline engine," Case Stud. Therm. Eng., vol. 6, pp. 147154, 2015.

[2] G. Najafi, B. Ghobadian, T. Yusaf, S. M. Safieddin Ardebili, and R. Mamat, "Optimization of performance and exhaust emission parameters of a SI (spark ignition) engine with gasoline-ethanol blended fuels using response surface methodology," Energy, vol. i, 2015.

[3] A. Elfasakhany, "Experimental study on emissions and performance of an internal combustion engine fueled with gasoline and gasoline/nbutanol blends," Energy Convers. Manag., vol. 88, pp. 277-283, 2014.

[4] V. Thangavel, S. Y. Momula, D. B. Gosala, and R. Asvathanarayanan, "Experimental studies on simultaneous injection of ethanol-gasoline and n-butanol-gasoline in the intake port of a four stroke SI engine," Renew. Energy, vol. 91, pp. 347-360, 2016.

[5] A. Elfasakhany and S. Arabia, "The Effects of Ethanol-Gasoline Blends on Performance and Exhaust Emission Characteristics of Spark Ignition Engines," vol. 4, no. 1.

[6] A. Elfasakhany, "Investigations on the effects of ethanol-methanolgasoline blends in a spark-ignition engine: Performance and emissions analysis," Eng. Sci. Technol. an Int. J., vol. 18, no. 4, pp. 713-719, 2015.

[7] J. Abel and S. Virtanen, "Corrosion of martensitic stainless steel in ethanol-containing gasoline: Influence of contamination by chloride, $\{\mathrm{H} 2 \mathrm{O}\}$ and acetic acid," Corros. Sci., vol. 98, pp. 318-326, 2015.

[8] H. S. Farkade and A. P. Pathre, "Experimental investigation of methanol, ethanol and butanol blends with gasoline on SI engine .," Int. J. Emerg. Technol. Adv. Eng., vol. 2, no. 4, pp. 205-215, 2012.

[9] G. Mendes, H. G. Aleme, and P. J. S. Barbeira, "Determination of octane numbers in gasoline by distillation curves and partial least squares regression," Fuel, vol. 97, pp. 131-136, 2012.

[10] J. Speight, Handbook of Petroleum Product Analysis, 2nd ed. Hoboken, New Jersey: John Wiley \& Sons, Inc., 2002.

[11] "Mothball additive in tanks gives fuel for thought - National - smh." [Online]. Available: http://www.smh.com.au/news/national/mothballadditive-in-tanks-gives-fuel-forthought/2007/08/07/1186252708319.html

[12] S. Liu, E. R. Cuty Clemente, T. Hu, and Y. Wei, "Study of spark ignition engine fueled with methanol/gasoline fuel blends," Appl. Therm. Eng., vol. 27, no. 11-12, pp. 1904-1910, 2007.

[13] J. M. and E. P. Sandrine Egraz, Brigitte Kajo, Martine Lézère, "Naphthalene," Lyon, France, 2002.

[14] I. Schifter, L. Diaz, R. Rodriguez, J. P. Gómez, and U. Gonzalez, "Combustion and emissions behavior for ethanol-gasoline blends in a single cylinder engine," Fuel, vol. 90, no. 12, pp. 3586-3592, 2011.
[15] R. A. Searles, "Car exhaust pollution: the role of precious metal catalysts in its control," Endeavour, vol. 13, no. 1, pp. 2-7, Jan. 1989.

About Author:

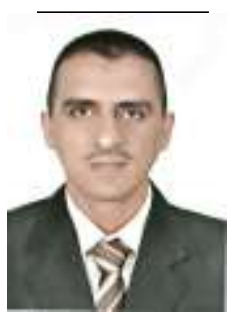

2000: BSc in Mechanical Engineering, University of Baghdad, Baghdad, Iraq 2004: MSc in Mechanical Engineering, University of Baghdad, Baghdad, Iraq 2012: PhD in Mechanical Engineering, UKM, Selangor, Malaysia Thermo-fluid, Internal combustion engines. 